\title{
STAT I
}

\section{VLIV ČESKÉ NÁRODNÍ BANKY NA MNOŽSTVÍ PENĚZ V EKONOMICE}

\author{
Zbyněk Revenda*
}

\section{Úvod}

Relativně novým přístupem centrálních bank v posledních letech bylo a je kvantitativní uvolňování. Kromě nejznámějšího přístupu ve snaze podpořit ekonomiku ve Spojených státech amerických k takovému kroku přistoupila anglická centrální banka. S poněkud jiným základním cílem, a to bránit deflačním tendencím, se ke kvantitativnímu uvolňování přidala Evropská centrální banka.

Základním motivem je zvýšit množství peněz v ekonomice. $\mathrm{K}$ tomu však často nedochází. Hlavní vysvětlení spočívá ve skutečnosti, že peníze do ekonomiky emitují obchodní banky a nikoli banka centrální.

V článku se zabýváme vývojem množství peněz v bankovním systému a ekonomice a hlavního způsobu jejich emise, bezhotovostními úvěry. Krátce se rovněž věnujeme oběživu.

Vztahy mezi vývojem množství peněz v bankovním systému a ekonomice jsou spojeny především s ochotou bank poskytovat bezhotovostní úvěry nebankovním klientům a s poptávkou po těchto úvěrech. Poměr obou veličin, tj. peněz v ekonomice a rezerv bank (včetně oběživa, tj. celkem měnové báze), je znám pod termínem peněžní multiplikátor. Může mít více podob, zejména $\mathrm{v}$ závislosti na tom, jak definujeme množství peněz v ekonomice, resp. v oběhu.

Úvěrová podstata emise peněz umožňuje podobným způsobem analyzovat vztahy mezi úvěry a měnovou bází, a to pomocí úvěrových multiplikátorů.

\footnotetext{
* Vysoká škola ekonomická v Praze, Fakulta financí a účetnictví (zbynek.revenda@vse.cz). Autor děkuje za pomoc se zpracováním dat Milanu Szaboovi.

Článek je zpracován jako výstup v rámci institucionální podpory VŠEIP 100040 na Vysoké škole ekonomické.
} 
Podobné analýzy v odborném tisku chybějí, což je hlavním vysvětlením kratšího seznamu literatury k tomuto článku. Časové období je zvoleno od konce roku 2008, kdy se již projevovaly kritické dopady vývoje ve světě na českou ekonomiku.

\section{Podoby kvantitativního uvolňování}

Kvantitativní uvolňování má více podob, nejpoužívanějšími jsou odkupy dluhových cenných papírů, nejčastěji státních, centrální bankou od bank, a snižování úrokových sazeb centrální banky až k nulovým a v některých případech i záporným hodnotám.

Atypickým je př́stup České národní banky, která po snížení úrokových sazeb na „technickou nulu“ (diskontní a repo sazba 0,05\% p. a. od listopadu 2012), opět ve snaze bránit deflaci, přistoupila v listopadu 2013 k masivním kursovým intervencím cestou odkupu zahraničních měn za koruny. Výsledkem bylo znehodnocení koruny z asi 25,8 na 27 korun za euro. To byl viditelný dopad, široce komentovaný odbornou i laickou veřejností. Naopak druhý významný efekt, prudký nárůst korunových rezerv bank, zůstal stranou pozornosti

Bylo již uvedeno, že primárním žádaným efektem kvantitativního uvolňování, at' již je jeho základním cílem podpora ekonomiky, či inflace, je zvýšení množství peněz v ekonomice. Někdy se i v odbornějším tisku objevují zavádějící tvrzení, že centrální banky takto zvyšují množství peněz v ekonomice. Nikoli, centrální banky peníze do ekonomiky neemitují.

Odkupy dluhových cenných papírů a popř. kursové intervence proti domácí měně mají bezprostřední, již zmíněný dopad na rezervy bank u centrální banky. Ve všech př́ípadech jde o bezhotovostní transakce, o nějakém často uváděném „tištění peněz" proto nelze uvažovat.

Snižování úrokových sazeb nemění objem rezerv bank. Centrální banka se tak snaží nepřímo podpořit poptávku po úvěrech od obchodních bank ze strany firem a domácností, nebot' předpokládá, že banky na snižování jejích sazeb budou reagovat rovněž snižováním vlastních úrokových sazeb. Efekt nemusejí mít jen levnější úvěry, ale také podpora investic a spotřeby před spořením, nebot' se samozřejmě snižují úrokové výnosy z vkladů.

Úvěrová aktivita bank je však na druhou stranu brzděna více faktory, mimo jiné rostoucími nároky na kapitálové vybavení bank, přitvrzováním dalších regulačních pravidel a nedostatkem kvalitních projektů. Poptávku po úvěrech brzdí např. odbytové potíže firem nebo pesimistické nálady spotřebitelů.

Rostoucí rezervy bank se tak neprojevují v adekvátním zvyšování množství peněz v oběhu, ale především v růstu cen cenných papírů na kapitálových trzích. Jinými slovy, peníze tak ,nejdou do reálné ekonomiky“.

\section{Oběživo a množství peněz v ekonomice}

Peníze mají dvě základní formy, hotovostní a bezhotovostní. Hotovostní forma v podobě mincí a později papírových státovek bankovek byla $\mathrm{v}$ podstatě jedinou formou peněz asi až do poslední třetiny 19. století, kdy se začínaly objevovat první bezhotovostní peníze v podobě vkladů na bankovních účtech. 
Vedle mincí z běžných kovů s nízkými nominálním hodnotami je hotovostní forma peněz, resp. oběživo, nyní představována papírovými (či plastickými) bankovkami. Jediným emitentem bankovek je centrální banka, která tedy má emisní monopol na bankovky. U mincí nemusí jít o centrální banku, do oběhu je může emitovat např̀. ministerstvo financí, ale v současnosti s ohledem na jejich význam jde o marginální záležitost. V České republice jsou emitovány opět centrální bankou.

Termín emise je však u oběživa mírně zavádějící. Ve skutečnosti se jeho množství mění především na základě poptávky nebankovních klientů s tím, že banky se v rámci každodenního řízení pokladní likvidity snaží poptávku uspokojovat. Jde především o zajištění dostatečného množství bankovek pro výběry z bankomatů. Pokud výběry oběživa jsou vyšší než jeho vklady na (zejména firemní) účty, v daný den a za jinak stejných okolností se množství oběživa v ekonomice zvýší.

Banky si mohou pokladní hotovost doplnit výběry ze svých účtů u centrální banky, což ovšem znamená, že růst jejich pokladní hotovosti se současně rovná poklesu jejich rezerv. $\mathrm{V}$ daném okamžiku se tedy nijak nemění měnová báze jako součet oběživa a rezerv bank - mění se pouze její struktura. ${ }^{1}$

$\mathrm{Na}$ základě rozvoje bezhotovostní formy, dramaticky urychlené v posledních dvaceti letech v přímé souvislosti s rozvojem internetu a mobilních technologií, které umožňují placení elektronickou cestou, by množství bezhotovostních peněz mělo nejen absolutně, ale také relativně růst. Relativním růstem máme na mysli růst podílu na celkovém množství peněz v ekonomice.

Termín množství peněz v ekonomice, resp. v oběhu, někdy také nabídka peněz, je obvykle vysvětlován pomocí měnových agregátů. Těchto agregátů je více, u nás dva pro potřeby analýz v rámci České republiky a tři spojené s harmonizací statistických dat $\mathrm{v}$ rámci Evropské unie. „Skutečným množstvím peněz v oběhu“ je pak zvolený měnový agregát v té které ekonomice, který pak nese označení peněžní zásoba.

V České republice ve sledovaném období konec roku 2008 až polovina roku 2014 vzrostly oběživo o 13,4\% a měnové agregáty $M 1$ o $57,8 \%$ a $M 2$ o 23,8 \%. M1 zahrnuje oběživo v rukách nebankovních subjektů a vklady těchto subjektů na běžných účtech v bankách. $M 2$ obsahuje $M 1$ a všechny další vklady nebankovních subjektů v bankách. Výrazně rychlejší růst $M 1$ je spojen s relativní preferencí běžných vkladů před dalšími vklady v bankách. ${ }^{2}$

Údaje v Tabulce 1 a Graf 1 nepotvrzují relativní ústup významu oběživa v České republice. Podíl na $M 1$ se sice snižuje, ale při zohlednění přesunů peněz z běžných účtů na jiné účty v bankách se podíl oběživa snížil jen nepatrně, o 1,1 procentního bodu. Základním vysvětlením je stále nedostatečné vybavení, především u malých prodejců, zařízeními umožňujícími bezhotovostní platby (ve spojení s relativně vysokými poplatky obchodníků za tyto platby) na jedné straně a obliba oběživa, resp. „nutnost placením“v hotovosti v sektorech šedé a černé ekonomiky na straně druhé.

1 Podrobně Revenda (2009).

2 Vysvětlení této skutečnosti by vyžadovalo podrobnou analýzu, proto jen zmíníme jeden z více možných důvodů: snižující se rozdíl mezi úročením termínovaných a dalších vkladů a běžných vkladů, tzn. pokles relativní atraktivity jiných vkladů ve srovnání s běžnými vklady. 
Tabulka 1

Oběživo a měnové agregáty v České republice (mil. CZK)

\begin{tabular}{|c|c|c|c|c|c|c|c|c|}
\hline Období & Oběživo & $\begin{array}{c}\text { Řetězový } \\
\text { index }\end{array}$ & M1 & $\begin{array}{c}\text { Řetězový } \\
\text { index }\end{array}$ & M2 & $\begin{array}{c}\text { Řetězový } \\
\text { index }\end{array}$ & $\begin{array}{c}\text { Oběživo } \\
\text { /M1 }\end{array}$ & $\begin{array}{c}\text { Oběživo } \\
\text { /M2 }\end{array}$ \\
\hline 2008 4. Q & 365547,6 & - & 1545267,6 & - & 2641123,2 & - & $23,7 \%$ & $13,8 \%$ \\
\hline 2009 1. Q & 359258,1 & $98,3 \%$ & 1549341,5 & $100,3 \%$ & 2644520,1 & $100,1 \%$ & $23,2 \%$ & $13,6 \%$ \\
\hline 2009 2. Q & 354316,8 & $98,6 \%$ & 1564393,9 & $101,0 \%$ & 2633533,9 & $99,6 \%$ & $22,6 \%$ & $13,5 \%$ \\
\hline 2009 3. Q & 351332,2 & $99,2 \%$ & 1591536,8 & $101,7 \%$ & 2622597,6 & $99,6 \%$ & $22,1 \%$ & $13,4 \%$ \\
\hline 2009 4. Q & 353557,1 & $100,6 \%$ & 1662261,7 & $104,4 \%$ & 2753145,0 & $105,0 \%$ & $21,3 \%$ & $12,8 \%$ \\
\hline 2010 1. Q & 351641,4 & $99,5 \%$ & 1661373,6 & $99,9 \%$ & 2730110,5 & $99,2 \%$ & $21,2 \%$ & $12,9 \%$ \\
\hline 2010 2. Q & 356495,9 & $101,4 \%$ & 1764545,2 & $106,2 \%$ & 2771129,9 & $101,5 \%$ & $20,2 \%$ & $12,9 \%$ \\
\hline 2010 3. Q & 355509,3 & $99,7 \%$ & 1835046,7 & $104,0 \%$ & 2746112,5 & $99,1 \%$ & $19,4 \%$ & $12,9 \%$ \\
\hline 20104. Q & 357510,1 & $100,6 \%$ & 1911242,9 & $104,2 \%$ & 2844951,8 & $103,6 \%$ & $18,7 \%$ & $12,6 \%$ \\
\hline 2011 1. Q & 358081,0 & $100,2 \%$ & 1903066,0 & $99,6 \%$ & 2797754,3 & $98,3 \%$ & $18,8 \%$ & $12,8 \%$ \\
\hline 2011 2. Q & 364297,9 & $101,7 \%$ & 1918468,7 & $100,8 \%$ & 2834101,5 & $101,3 \%$ & $19,0 \%$ & $12,9 \%$ \\
\hline 2011 3. Q & 368289,6 & $101,1 \%$ & 1945873,9 & $101,4 \%$ & 2868907,0 & $101,2 \%$ & $18,9 \%$ & $12,8 \%$ \\
\hline 20114. Q & 377942,1 & $102,6 \%$ & 2041534,8 & $104,9 \%$ & 2994093,5 & $104,4 \%$ & $18,5 \%$ & $12,6 \%$ \\
\hline 2012 1. Q & 379210,2 & $100,3 \%$ & 2035280,6 & $99,7 \%$ & 2978484,4 & $99,5 \%$ & $18,6 \%$ & $12,7 \%$ \\
\hline 2012 2. Q & 386484,4 & $101,9 \%$ & 2080148,3 & $102,2 \%$ & 3018751,3 & $101,4 \%$ & $18,6 \%$ & $12,8 \%$ \\
\hline 2012 3. Q & 386421,7 & $100,0 \%$ & 2100012,9 & $101,0 \%$ & 3022593,8 & $100,1 \%$ & $18,4 \%$ & $12,8 \%$ \\
\hline 2012 4. Q & 388879,5 & $100,6 \%$ & 2212771,8 & $105,4 \%$ & 3129476,5 & $103,5 \%$ & $17,6 \%$ & $12,4 \%$ \\
\hline 2013 1. Q & 391662,8 & $100,7 \%$ & 2210307,5 & $99,9 \%$ & 3112846,1 & $99,5 \%$ & $17,7 \%$ & $12,6 \%$ \\
\hline 2013 2. Q & 399431,3 & $102,0 \%$ & 2252403,0 & $101,9 \%$ & 3147626,0 & $101,1 \%$ & $17,7 \%$ & $12,7 \%$ \\
\hline 2013 3. Q & 399126,8 & $99,9 \%$ & 2282725,8 & $101,3 \%$ & 3176667,7 & $100,9 \%$ & $17,5 \%$ & $12,6 \%$ \\
\hline 20134. Q & 405445,2 & $101,6 \%$ & 2380255,1 & $104,3 \%$ & 3278654,6 & $103,2 \%$ & $17,0 \%$ & $12,4 \%$ \\
\hline 2014 1. Q & 405280,0 & $100,0 \%$ & 2389409,7 & $100,4 \%$ & 3271767,6 & $99,8 \%$ & $17,0 \%$ & $12,4 \%$ \\
\hline 2014 2. Q & 414533,7 & $102,3 \%$ & 2439019,8 & $102,1 \%$ & 3270805,2 & $100,0 \%$ & $17,0 \%$ & $12,7 \%$ \\
\hline
\end{tabular}

Pramen: ARAD, měnový přehled České republiky, vlastní výpočty

\section{Graf 1}

\section{Podíl oběživa na měnových agregátech}

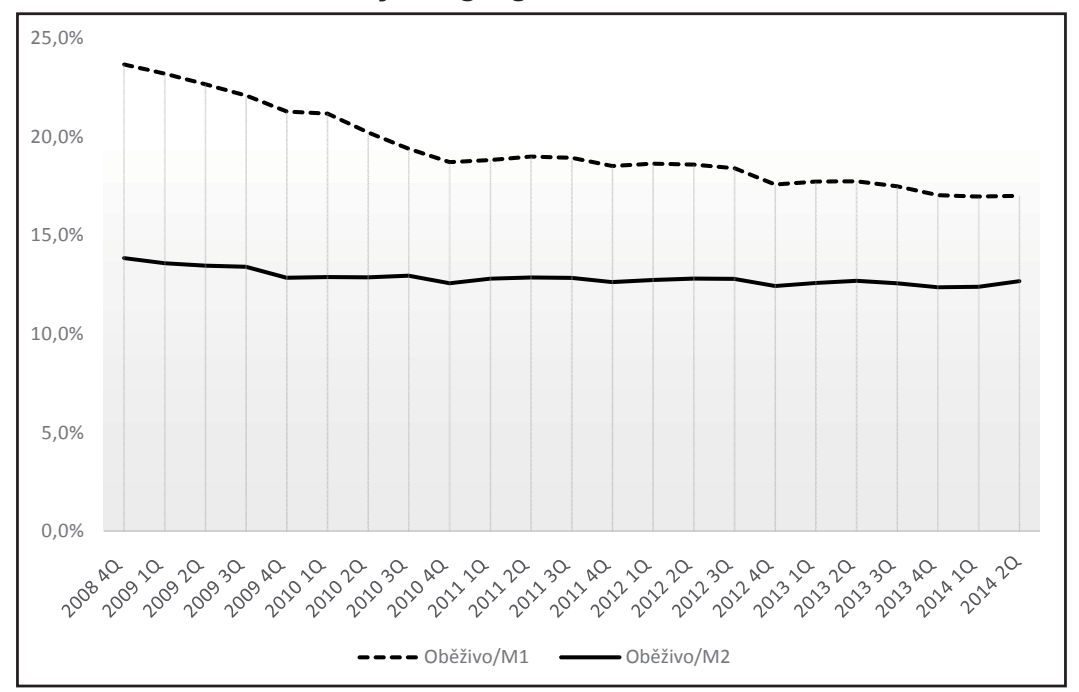

Pramen: Údaje z Tabulky 1 
Vzhledem ke struktuře „množství peněz v oběhu“, at' již v podobě $M 1$ nebo $M 2$, je zřejmé, že neplatí tvrzení o tom, že centrální banka - pomocí svých nástrojů - řídí (či dokonce určuje) celkové množství peněz v ekonomice. ${ }^{3}$ Centrální banka může toto množství ovlivňovat, ale jen velmi nepř́imo, a někdy je její snaha podpořit růst množství peněz téměř neúčinná (viz zejm. část 5).

Vysvětlení je snadné - přes $80 \%$ M1 představují běžné vklady v obchodních bankách, což rozhodně nejsou peníze pod kontrolou centrální banky. Také vývoj oběživa je závislý na poptávce po oběživu ze strany nebankovních subjektů a na ní následně závislé poptávce obchodních bank po oběživu od centrální banky. Připomínáme, že výběry oběživa bankami současně znamenají pokles jejich bezhotovostních rezerv. Změny oběživa jsou tudíž nezávislé na centrální bance. ${ }^{4}$

\section{Rezervy bank, měnová báze a peněžní multiplikátory}

Centrální banky mohou vývoj množství peněz v ekonomice ovlivňovat regulací rezerv bank, a to různými způsoby s různou účinností. Nejúčinnější jsou operace na volném trhu v podobě nákupů či prodejů dluhových cenných papírů mezi centrální bankou a obchodními bankami. Hlavním neprímým nástrojem jsou změny úrokových sazeb centrální banky. ${ }^{5}$ Vysoce účinné mohou být kursové intervence, primárně orientované na změnu (vývoje) měnového kursu. Dopady intervencí na rezervy bank mohou být neutralizovány, resp. sterilizovány, pomocí operací s cennými papíry. Nejsou-li sterilizovány, plně se projeví ve změně rezerv bank.

Vývoj celkového množství peněz v oběhu následně závisí především na poptávce po úvěrech nebankovními subjekty od obchodních bank a na ochotě bank tyto úvěry poskytovat (nabídka úvěrů). Jde samozřejmě téměř výhradně o bezhotovostní úvěry.

Rezervy bank se mohou měnit i v důsledku poptávky nebankovních klientů po oběživu, nebo jeho nabídkou obchodním bankám, tj. ukládáním oběživa do bank.

Další možností změn rezerv bank jsou obchody se zahraničními měnami na mezibankovním trhu. Není-li protistranou centrální banka, pak se v zásadě celkové množství rezerv bank nemění, dochází ke zvýšení rezerv u prodávajících bank a k poklesu rezerv u nakupujících bank. Stejné poznámky se vztahují na další transakce na mezibankovním trhu a zúčtování bezhotovostních transakcí mezi bankami v clearingovém centru centrální banky.

Klíčem k analýze vývoje množství peněz v souvislosti s možnostmi centrální banky toto ovlivnit jsou peněžní multiplikátory, které vyjadřují poměr měnových agregátů k měnové bázi. Zde je nutné uvést jednu skutečnost, ke které se podrobněji vrátíme v části 5. Obchodní banky emitují bezhotovostní peníze především poskytováním

3 Jde o časté tvrzení mnohých představitelů tzv. rakouské školy; srov. např. Hülsmann (2003).

4 Jedinou výjimkou je rozhodování centrální banky o poskytnutí hotovostního úvěru obchodní bance. To současně znamená, že poptávka obchodní banky převyšuje objem dostupných rezerv u centrální banky. Je to krizová situace hotovostní likvidity, klienti banky „ve velkém“ vyzvedávají ze svých účtů oběživo - jde o nejznámější podobu tzv. bankovního runu. Podrobný popis emise peněz centrální bankou je v Revenda (2009).

5 Podrobně např. Rasche a Williams (2007). 
bezhotovostních úvěrů nebankovním klientům. Poskytnutý úvěr současně znamená objemově stejné zvýšení prostředků na běžném účtu dlužníka. Použití půjčených peněz ve prospěch jiného klienta nemění celkový objem prostředků na běžných vkladech v obchodních bankách. Platí tedy, že nově poskytnuté úvěry (snížené o splácené úvěry) odpovídají zvýšení běžných vkladů, a tím měnových agregátů.

Růst peněžních multiplikátorů představuje vyšší úvěrovou aktivitu obchodních bank (a zvýšenou poptávku po úvěrech), pokles znamená opak. Bylo již zmíněno, že roli mohou mít i regulační pravidla, resp. jejich změny. Údaje o vývoji rezerv bank, měnové báze a peněžních multiplikátorů jsou uvedeny v Tabulce 2 .

\section{Tabulka 2}

Rezervy bank a měnová báze $v$ České republice

\begin{tabular}{|c|c|c|c|c|c|c|}
\hline Období & Rezervy bank & $\begin{array}{c}\text { Řetězový } \\
\text { index }\end{array}$ & $\begin{array}{l}\text { Měnová báze } \\
\text { (MB) }\end{array}$ & $\begin{array}{l}\text { Řetězový } \\
\text { index }\end{array}$ & $\begin{array}{l}\mathrm{pm} 1= \\
\mathrm{M} 1 / \mathrm{MB}\end{array}$ & $\begin{array}{l}\mathrm{pm} 2= \\
\mathrm{M} 2 / \mathrm{MB}\end{array}$ \\
\hline 2008 4. Q & 269843,3 & - & 669091,1 & - & 2,31 & 3,95 \\
\hline 2009 1. Q & 393730,0 & $145,9 \%$ & 780305,0 & $116,6 \%$ & 1,99 & 3,39 \\
\hline 2009 2. Q & 391417,0 & $99,4 \%$ & 776230,0 & $99,5 \%$ & 2,02 & 3,39 \\
\hline 2009 3. Q & 396569,0 & $101,3 \%$ & 777132,0 & $100,1 \%$ & 2,05 & 3,37 \\
\hline $20094 . Q$ & 380964,0 & $96,1 \%$ & 768240,0 & $98,9 \%$ & 2,16 & 3,58 \\
\hline $20101 . Q$ & 415418,0 & $109,0 \%$ & 795484,0 & $103,5 \%$ & 2,09 & 3,43 \\
\hline 2010 2. Q & 415505,0 & $100,0 \%$ & 800866,0 & $100,7 \%$ & 2,20 & 3,46 \\
\hline 2010 3. Q & 415545,0 & $100,0 \%$ & 801261,0 & $100,0 \%$ & 2,29 & 3,43 \\
\hline 2010 4. Q & 392775,0 & $94,5 \%$ & 784469,0 & $97,9 \%$ & 2,44 & 3,63 \\
\hline $20111 . Q$ & 421190,0 & $107,2 \%$ & 807181,0 & $102,9 \%$ & 2,36 & 3,47 \\
\hline $20112 . Q$ & 411103,0 & $97,6 \%$ & 805428,0 & $99,8 \%$ & 2,38 & 3,52 \\
\hline 20113. Q & 402355,0 & $97,9 \%$ & 800312,0 & $99,4 \%$ & 2,43 & 3,58 \\
\hline 2011 4. Q & 386020,0 & $95,9 \%$ & 797973,0 & $99,7 \%$ & 2,56 & 3,75 \\
\hline 2012 1. Q & 405095,0 & $104,9 \%$ & 813617,0 & $102,0 \%$ & 2,50 & 3,66 \\
\hline 2012 2. Q & 398642,0 & $98,4 \%$ & 813589,0 & $100,0 \%$ & 2,56 & 3,71 \\
\hline 2012 3. Q & 393515,0 & $98,7 \%$ & 809100,0 & $99,4 \%$ & 2,60 & 3,74 \\
\hline 2012 4. Q & 383642,0 & $97,5 \%$ & 806349,0 & $99,7 \%$ & 2,74 & 3,88 \\
\hline 2013 1. Q & 444967,0 & $116,0 \%$ & 866563,0 & $107,5 \%$ & 2,55 & 3,59 \\
\hline 2013 2. Q & 453959,0 & $102,0 \%$ & 883623,0 & $102,0 \%$ & 2,55 & 3,56 \\
\hline 2013 3. Q & 459740,0 & $101,3 \%$ & 889287,0 & $100,6 \%$ & 2,57 & 3,57 \\
\hline 2013 4. Q & 664077,0 & $144,4 \%$ & 1105924,0 & $124,4 \%$ & 2,15 & 2,96 \\
\hline 2014 1. Q & 711288,0 & $107,1 \%$ & 1147479,0 & $103,8 \%$ & 2,08 & 2,85 \\
\hline 2014 2. Q & 721159,0 & $101,4 \%$ & 1166805,0 & $101,7 \%$ & 2,09 & 2,80 \\
\hline
\end{tabular}

Pramen: Bilance ČNB, vlastní výpočty

Poznámka: Rezervy bank a měnová báze v mil. CZK

Vysvětlivky:

Rezervy bank = závazky ČNB vůči tuzemským bankám sní̌ené o pohledávky ČNB vůči tuzemským bankám

Rozdíl měnové báze a rezerv bank = oběživo v rukách nebankovních subjektů a pokladní hotovost bank. 
Podíl rezerv bank v měnové bázi dlouhodobě roste, na konci roku 2008 činil 40,3 \% a v polovině roku 2014 již 61,8\%. Zdaleka nejvyšší relativní tříměsíční růst zaznamenaly rezervy bank v prvním čtvrtletí 2009 a ve čtvrtém čtvrtletí 2013. V prvním př́padě byly hlavními důvody jednorázové převedení prostředků státního rozpočtu z obchodních bank do centrální banky na konci roku 2008 a snížení půjček obchodních bank od centrální banky v prvním čtvrtletí 2009. ${ }^{6}$ Druhý případ je jednoznačně spojen s intervencemi České národní banky proti koruně počátkem listopadu 2013 v rozsahu 200 miliard CZK.

Pokud jde o strukturu rezerv, podíl povinných minimálních rezerv na celkových rezervách se permanentně snižoval, a to z $16 \%$ na začátku sledovaného období na $8 \%$ na jeho konci - zbývajících $84 \%$, resp. $92 \%$, představují tzv. (dobro)volné rezervy bank. $^{7}$

Ve sledovaném období se rezervy bank zvýšily o 167,3\% a měnová báze o 74,4\%. Z logiky konstrukce peněžních multiplikátorů jako poměrů měnových agregátů k měnové bázi pak plyne, že se musejí snížit, nedojde-li současně k dramatickému zvýšení bezhotovostních úvěrů obchodních bank nebankovním dlužníkům. K tomu ani $\mathrm{v}$ jednom $\mathrm{z}$ těchto prŕṕpadů nedošlo. ${ }^{8}$

\section{Vklady a úvěry}

V předchozí části byl uveden základní způsob emise bezhotovostních peněz do ekonomiky. Je to bezhotovostní úvěr, který je obchodní bankou poskytnut nebankovnímu dlužníkovi.

Poskytne-li bezhotovostní úvěr centrální banka, dlužníkem je vždy obchodní (popř. jiná) banka. Dojde ke zvýšení rezerv př́íslušné banky na straně pasiv centrální banky a souběžně se zvýší aktiva - pohledávky centrální banky. Bance - dlužníkovi vzrostou rezervy $\mathrm{v}$ jejích aktivech a závazky vůči věřiteli - centrální bance. Vzroste tedy měnová báze, ale množství peněz v ekonomice se nezmění.

Obchodní banky si za různými účely vzájemně poskytují obvykle vysoce krátkodobé půjčky na mezibankovním trhu. Ve všech těchto případech se nemění ani měnová báze ani měnové agregáty. Mění se pouze výše rezerv jednotlivých bank - sníží se u věřitelských a zvýší u dlužnických bank.

Zde je proto vhodné korigovat dost široce přijímaná tvrzení o růstu spořivosti domácností a bezpečnosti bankovního systému, ve kterém jsou vklady vyšší než poskytnuté úvěry.

Růst celkových vkladů je spojen především s poskytovanými bezhotovostními úvěry bank. Jak jinak by ještě vklady mohly růst, abstrahujeme-li od vlivu zahraničně-obchodních vztahů? Jedině ukládáním oběživa na účty, o čemž údaje o vývoji oběživa

\footnotetext{
6 Rezervy bank snižujeme o jejich závazky vůči centrální bance, srov. poznámka pod Tabulkou 2.

7 Volné či dobrovolné rezervy mohou být označovány i termínem přebytečné, setkat se lze také s termínem volná likvidita bank. V textu je budeme označovat za dobrovolné.

8 Blíže další výklad, zejm. údaje v Tabulce 4.
} 
u nás rozhodně nesvědčí. Samozřejmě vklady domácností rostou také díky bezhotovostnímu vyplácení mezd, sociálních dávek atp. To však znamená, že se snižují vklady vyplácejících subjektů. ${ }^{9}$

Celkové vklady v bankách ve sledovaném období vzrostly o 25,5\%, vklady domácností o 28,6\% a vklady podniků o 16,9\%. Bezhotovostní nákupy spotřebitelů znamenají především přesuny z vkladů domácností na účty podniků. ${ }^{10}$ Výrazně rychlejší růst vkladů domácností je jedním z projevů odkladu spotřeby v souvislosti s chabým ekonomickým vývojem a deflačními tendencemi; blíže Tabulka 3.

Tabulka 3

Vklady v bankách v České republice (mil. CZK)

\begin{tabular}{|c|c|c|c|c|c|c|}
\hline Období & Vklady celkem & $\begin{array}{c}\text { Řetězový } \\
\text { index }\end{array}$ & $\begin{array}{l}\text { Domácnosti - } \\
\text { vklady }\end{array}$ & $\begin{array}{c}\text { Řetězový } \\
\text { index }\end{array}$ & $\begin{array}{l}\text { Podniky - } \\
\text { vklady }\end{array}$ & $\begin{array}{l}\text { Řetězový } \\
\text { index }\end{array}$ \\
\hline 2008 4. Q & 2275575,6 & - & 1504973,4 & - & 664366,9 & - \\
\hline 2009 1. Q & 2285262,0 & $100,4 \%$ & 1561615,3 & $103,8 \%$ & 601472,2 & $90,5 \%$ \\
\hline 2009 2. Q & 2279217,1 & $99,7 \%$ & 1579941,3 & $101,2 \%$ & 592778,2 & $98,6 \%$ \\
\hline 2009 3. Q & 2271265,4 & $99,7 \%$ & 1584915,2 & $100,3 \%$ & 577084,1 & $97,4 \%$ \\
\hline 2009 4. Q & 2399587,9 & $105,6 \%$ & 1616026,4 & $102,0 \%$ & 676271,3 & $117,2 \%$ \\
\hline $20101 . Q$ & 2378469,1 & $99,1 \%$ & 1637272,0 & $101,3 \%$ & 624839,3 & $92,4 \%$ \\
\hline 2010 2. Q & 2414634,0 & $101,5 \%$ & 1662248,2 & $101,5 \%$ & 647545,5 & $103,6 \%$ \\
\hline 2010 3. Q & 2390603,2 & $99,0 \%$ & 1661322,4 & $99,9 \%$ & 627099,4 & $96,8 \%$ \\
\hline $20104 . Q$ & 2487441,7 & $104,1 \%$ & 1694743,9 & $102,0 \%$ & 687406,4 & $109,6 \%$ \\
\hline $20111 . Q$ & 2439673,3 & $98,1 \%$ & 1718865,0 & $101,4 \%$ & 626901,5 & $91,2 \%$ \\
\hline $20112 . Q$ & 2469803,6 & $101,2 \%$ & 1746182,8 & $101,6 \%$ & 624600,5 & $99,6 \%$ \\
\hline 2011 3. Q & 2500617,4 & $101,2 \%$ & 1762798,3 & $101,0 \%$ & 642641,3 & $102,9 \%$ \\
\hline $20114 . Q$ & 2616151,4 & $104,6 \%$ & 1777293,9 & $100,8 \%$ & 721569,7 & $112,3 \%$ \\
\hline 2012 1. Q & 2599274,2 & $99,4 \%$ & 1802234,8 & $101,4 \%$ & 678042,5 & $94,0 \%$ \\
\hline 2012 2. Q & 2632266,9 & $101,3 \%$ & 1816526,7 & $100,8 \%$ & 699703,6 & $103,2 \%$ \\
\hline 2012 3. Q & 2636172,1 & $100,1 \%$ & 1829668,8 & $100,7 \%$ & 680843,4 & $97,3 \%$ \\
\hline 2012 4. Q & 2740597,0 & $104,0 \%$ & 1846816,3 & $100,9 \%$ & 754493,3 & $110,8 \%$ \\
\hline $20131 . Q$ & 2721183,3 & $99,3 \%$ & 1878972,8 & $101,7 \%$ & 702548,0 & $93,1 \%$ \\
\hline 2013 2. Q & 2748194,7 & $101,0 \%$ & 1875519,7 & $99,8 \%$ & 721145,7 & $102,6 \%$ \\
\hline 2013 3. Q & 2777540,9 & $101,1 \%$ & 1873117,7 & $99,9 \%$ & 733944,2 & $101,8 \%$ \\
\hline 2013 4. Q & 2873209,4 & $103,4 \%$ & 1883046,8 & $100,5 \%$ & 820706,5 & $111,8 \%$ \\
\hline $20141 . Q$ & 2866487,6 & $99,8 \%$ & 1911145,8 & $101,5 \%$ & 784891,0 & $95,6 \%$ \\
\hline 2014 2. Q & 2856271,5 & $99,6 \%$ & 1934977,0 & $101,2 \%$ & 776495,7 & $98,9 \%$ \\
\hline
\end{tabular}

Pramen: ARAD, vlastní výpočty

Poznámka: Součet vkladů domácností a podniků je nižší než vklady celkem. Rozdíl představují vklady finančních institucí a státu.

9 Určité modifikace jsou spojeny se situací, kdy státní výdaje jsou hrazeny z prostředků na účtech u centrální banky, které nejsou součástí měnových agregátů. Pozorný čtenář by našel i některé další možnosti, objemově však zcela nevýznamné.

10 To nemusí vždy platit, domácnost či spotřebitel může platit jinému spotřebiteli, státu (daně) atp. 
Pokud jde o bezpečnost bankovního systému posuzovanou poměrem celkových úvěrů a celkových vkladů v bankách, v ČR na konci roku 2008 činil 0,854 a v polovině 2014 již jen 0,803 .

Vyšší stav vkladů znamená, že banky jejich část „investuji““ do státních cenných papírů a zejména do rezerv u centrální banky. Protože úročení rezerv je výrazně nižší, než je průměrné úročení úvěrů, banky ztrácejí potenciální výnosy. To se týká dobrovolných rezerv jako rozdílu mezi celkovými a povinnými minimálními rezervami. Ve sledovaném období se povinné minimální rezervy postupně zvyšovaly - díky růstu základny jejich výpočtu, tj. vkladů nebankovních subjektů se splatností do dvou let ze 43 na 60 mld. korun. Dobrovolné rezervy tak dosahují obrovských objemů, mezi 230 a 660 mld. korun. ${ }^{11}$ Česká národní banka je úročila tzv. repo sazbou, spojenou s prodávanými vlastními cennými papíry bankám.

Od 2. listopadu 2012 je repo sazba na úrovni diskontní sazby ( $0,05 \%$ p. a.), kterou se bankám úročí povinné minimální rezervy. To znamená konec dřívějších objemově značných prodejů cenných papírů centrální banky obchodním bankám, nebot' banky při splnění určitých podmínek získávají stejné úroky i z dobrovolných rezerv.

Klesající poměr mezi úvěry a vklady tak skutečně znamená určité zvýšení bezpečnosti bankovního systému, nebot' poskytované úvěry nebankovním klientům jsou spojeny s vyšším rizikem než státní cenné papíry. Riziko rezerv bank je nulové. Na druhou stranu jsou tato bezpečná aktiva spojena s nízkými výnosy. Vyšší bezpečnost bank je vykoupena nižší ziskovostí. ${ }^{12}$

Ani za těchto okolností banky nijak výrazně nezvýšily úvěrovou aktivitu. Kromě zpřísňování regulačních pravidel (Basel III) jsou hlavními důvody nedostatečná bonita dlužníků a nedostatek kvalitních investičních projektů. Údaje o vývoji úvěrů jsou v Tabulce 4.

Celkové úvěry se v polovině roku 2014 zvýšily ve srovnání s koncem 2008 o 18,0 \%, tj. o 7,5 procentního bodu méně než celkové vklady. Stav zadlužení domácností vůči bankám se naopak zvýšil o 38,7\% (o 10,1 procentního bodu více než vklady), zatímco úvěry podnikům dokonce klesly o $0,4 \%$. Údaje potvrzují výše uvedené poznámky o odkladu spotřeby, opatrnosti bank při poskytování úvěrů aj.

11 Připomeňme skokový nárůst v listopadu 2013 vlivem kursových intervencí.

12 Možné kompenzace nižší výnosnosti aktiv zvyšováním poplatků za bankovní služby a jinými způsoby necháváme stranou pozornosti. 


\section{Tabulka 4}

Bankovní úvěry v České republice (mil. CZK)

\begin{tabular}{|c|c|c|c|c|c|c|c|}
\hline Období & $\begin{array}{l}\text { Úvěry } \\
\text { celkem }\end{array}$ & $\begin{array}{c}\text { Řetězový } \\
\text { index }\end{array}$ & $\begin{array}{l}\text { Úvěry } \\
\text { domác- } \\
\text { nostem }\end{array}$ & $\begin{array}{c}\text { Řetězový } \\
\text { index }\end{array}$ & $\begin{array}{c}\text { Úvěry } \\
\text { podnikům }\end{array}$ & $\begin{array}{c}\text { Řetězový } \\
\text { index }\end{array}$ & $\begin{array}{c}\text { Úvěrový } \\
\text { multi- } \\
\text { plikátor }\end{array}$ \\
\hline 2008 4. Q & 1944125,6 & - & 880220,8 & - & 1009626,0 & - & 2,91 \\
\hline 2009 1. Q & 1949469,1 & $100,3 \%$ & 906389,0 & $103,0 \%$ & 989730,7 & $98,0 \%$ & 2,50 \\
\hline 2009 2. Q & 1964813,8 & $100,8 \%$ & 933357,4 & $103,0 \%$ & 975061,8 & $98,5 \%$ & 2,53 \\
\hline 2009 3. Q & 1971172,0 & $100,3 \%$ & 958725,9 & $102,7 \%$ & 953719,7 & $97,8 \%$ & 2,54 \\
\hline 2009 4. Q & 1972749,8 & $100,1 \%$ & 983304,1 & $102,6 \%$ & 921751,5 & $96,6 \%$ & 2,57 \\
\hline $20101 . Q$ & 1959900,3 & $99,3 \%$ & 993351,9 & $101,0 \%$ & 900975,3 & $97,7 \%$ & 2,46 \\
\hline 2010 2. Q & 1980613,6 & $101,1 \%$ & 1011805,7 & $101,9 \%$ & 903863,1 & $100,3 \%$ & 2,47 \\
\hline 2010 3. Q & 2002438,5 & $101,1 \%$ & 1038193,0 & $102,6 \%$ & 900247,3 & $99,6 \%$ & 2,50 \\
\hline 2010 4. Q & 2027179,0 & $101,2 \%$ & 1057079,4 & $101,8 \%$ & 905212,7 & $100,6 \%$ & 2,58 \\
\hline $20111 . Q$ & 2040337,9 & $100,6 \%$ & 1064005,5 & $100,7 \%$ & 912785,7 & $100,8 \%$ & 2,53 \\
\hline 2011 2. Q & 2074545,1 & $101,7 \%$ & 1080074,8 & $101,5 \%$ & 933337,0 & $102,3 \%$ & 2,58 \\
\hline 2011 3. Q & 2106708,1 & $101,6 \%$ & 1097758,0 & $101,6 \%$ & 947675,3 & $101,5 \%$ & 2,63 \\
\hline $20114 . Q$ & 2133920,3 & $101,3 \%$ & 1118066,2 & $101,8 \%$ & 951661,3 & $100,4 \%$ & 2,67 \\
\hline 2012 1. Q & 2138380,7 & $100,2 \%$ & 1121929,5 & $100,3 \%$ & 954845,4 & $100,3 \%$ & 2,63 \\
\hline 2012 2. Q & 2167521,8 & $101,4 \%$ & 1133821,7 & $101,1 \%$ & 964556,9 & $101,0 \%$ & 2,66 \\
\hline 2012 3. Q & 2169530,5 & $100,1 \%$ & 1144694,5 & $101,0 \%$ & 964444,2 & $100,0 \%$ & 2,68 \\
\hline 2012 4. Q & 2185293,1 & $100,7 \%$ & 1163318,8 & $101,6 \%$ & 960322,7 & $99,6 \%$ & 2,71 \\
\hline $20131 . Q$ & 2211939,9 & $101,2 \%$ & 1193523,3 & $102,6 \%$ & 976005,5 & $101,6 \%$ & 2,55 \\
\hline 2013 2. Q & 2205251,1 & $99,7 \%$ & 1163962,8 & $97,5 \%$ & 982416,6 & $100,7 \%$ & 2,50 \\
\hline 2013 3. Q & 2229268,0 & $101,1 \%$ & 1178445,3 & $101,2 \%$ & 968212,9 & $98,6 \%$ & 2,51 \\
\hline 2013 4. Q & 2260711,1 & $101,4 \%$ & 1206290,4 & $102,4 \%$ & 995703,2 & $102,8 \%$ & 2,04 \\
\hline $20141 . Q$ & 2260720,3 & $100,0 \%$ & 1210267,1 & $100,3 \%$ & 990925,9 & $99,5 \%$ & 1,97 \\
\hline 2014 2. Q & 2294140,6 & $101,5 \%$ & 1221098,6 & $100,9 \%$ & 1005808,6 & $101,5 \%$ & 1,97 \\
\hline
\end{tabular}

Pramen: ARAD, vlastní výpočty

Poznámka: Součet úvěrů domácnostem a podnikům je nižší než úvěry celkem. Rozdíl představují úvěry finančním institucím a státu.

\section{Multiplikátory}

Poslední sloupec Tabulky 4 zachycuje tzv. úvěrový multiplikátor. V měnové oblasti se mnohem častěji pracuje s peněžními multiplikátory. Jde vždy o podíly př́islušných měnových agregátů na měnové bázi; srov. Tabulku 2. Jejich stabilita či nestabilita v zásadě vypovídají o možnostech centrální banky ovlivňovat vývoj množství peněz v ekonomice. Údaje za Českou republiku jsou zpracovány v Grafu 2. 


\section{Graf 2}

\section{Vývoj multiplikátorů}

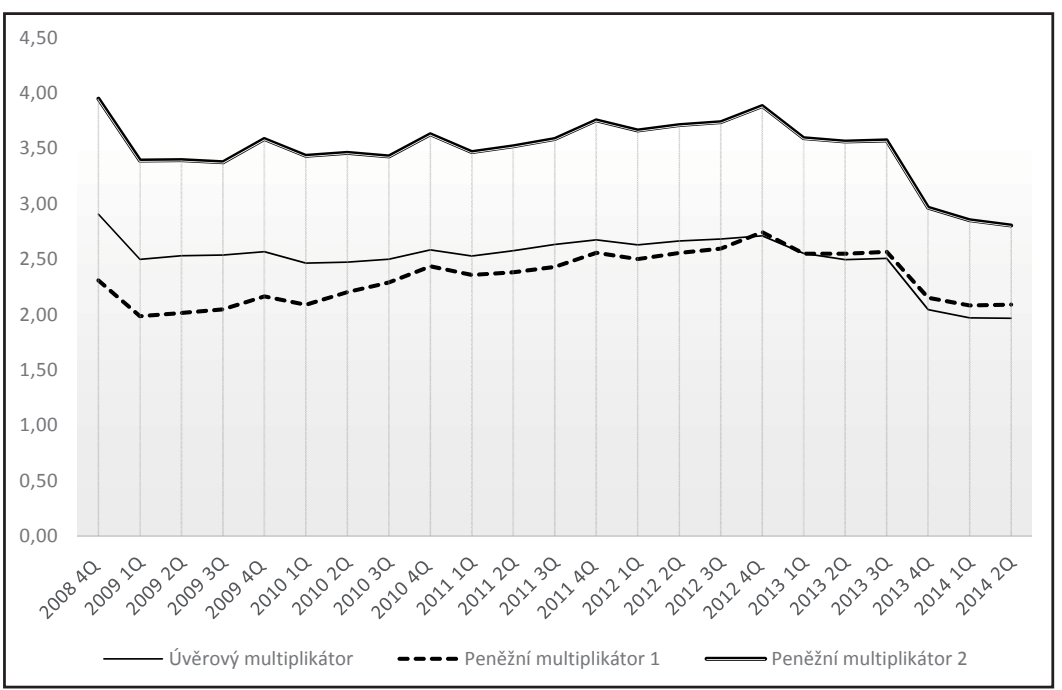

Postup spojený s dominantní rolí množství peněz v oběhu - v podobě vybraného měnového agregátu, tj. peněžní zásoby - nese označení monetaristický proces měnové politiky. Jednou ze základních námitek proti jeho smysluplnosti je právě nestabilita vazby mezi peněžní zásobou a měnovou bází. Zatímco měnovou bázi, resp. rezervy bank, může centrální banka ovlivňovat velmi efektivně, její vliv na peněžní zásobu je spojený se stabilitou peněžního multiplikátoru nebo alespoň se schopností (či dokonce „uměním“) centrálních bankéřů odhadnout jeho vývoj.

Je nutné upozornit, že naše centrální banka takto nepostupuje, od roku 1998 má její měnová politika podobu cílování inflace. Měnové agregáty spolu s dalšími veličinami plní pouze roli indikátorů měnového vývoje, což může být jednou z více příčin nestability multiplikátoru. Určit, jaký podíl má odklon od politiky ovlivňování peněžní zásoby na této nestabilitě, by bylo pouhou spekulací.

Úvěrový multiplikátor je zde v podobě podílu bankovních úvěrů nebankovním subjektům na měnové bázi. Ve srovnání s peněžními multiplikátory je stabilnější až do konce roku 2012.

V Grafu 2 je nápadný výrazný pokles v 1. čtvrtletí 2009; šlo o určité dozvuky vrcholu finanční krize $\mathrm{v}$ souvislosti s pádem americké investiční banky Lehman Brothers v polovině září 2008. ${ }^{13}$ Prudké propady multiplikátorů v poslední čtvrtině roku 2013 jednoznačně souvisejí s masivními intervencemi České národní banky.

13 Peněžní multiplikátory klesly také v roce 2008 ve srovnání s rokem 2007, viz Revenda (2013), tab. 2.1. Ve Spojených státech amerických je multiplikátor měnového agregátu $M 1$ od roku 2008 dokonce nižší než 1 , pohybuje se kolem hodnoty 0,9 ; bliže tamtéž, Tab. 2.3. Běžné vklady v bankách jsou nižší než rezervy bank. Jde o projev kvantitativního uvolňování a reakci bank na finanční krizi. Hlavním vlivem je enormní nárůst rezerv bank, často v podobě půjček od Federálního rezervního systému. Rezervy jsou bankami umist'ovány do instrumentů kapitálového trhu a stojí tak, mimo jiné faktory, za rychlým růstem akciových indexů. Podrobný rozbor zejm. Gavin (2009) a Musílek (2010). 
Dochází rovněž ke sbližování hodnot obou peněžních multiplikátorů z důvodu výrazně rychlejšího růstu měnového agregátu $M 1$ ve srovnání s růstem $M 2$, tzn. relativní růst běžných vkladů ve srovnání s dalšími vklady v bankách.

Centrální banka samozřejmě může vývoj peněžních multiplikátorů ovlivnit. Ukažme si možnosti na multiplikátoru měnového agregátu $M 1$ (pm1).

$$
\begin{aligned}
& M 1=\text { oběživo }(\mathrm{OB})+\text { běžné vklady }(\mathrm{BV}) \\
& \text { Měnová báze }(\mathrm{MB})=\text { oběživo + rezervy bank }(\mathrm{RB})
\end{aligned}
$$

Nyní budeme abstrahovat od rozdílu v oběživu, kdy v měnové bázi navíc figuruje pokladní hotovost bank. Budeme předpokládat existenci povinných minimálních rezerv (PMR) stanovených sazbou (r) z běžných vkladů a vkladů se splatností do 2 let (SV):

$$
\mathrm{PMR}=\mathrm{r}_{\mathrm{BV}} \cdot \mathrm{BV}+\mathrm{r}_{\mathrm{SV}} \cdot \mathrm{SV}
$$

Rozdíl mezi celkovými povinnými minimálními rezervami bank tvoří dobrovolné rezervy bank (DOR):

$$
\mathrm{RB}=\mathrm{PMR}+\mathrm{DOR}
$$

Nyní provedeme rozklad peněžního multiplikátoru s cílem identifikovat konkrétní determinanty, které určují jeho výši.

$$
\begin{aligned}
p m 1 & =M 1 / \mathrm{MB} \\
& =\frac{\mathrm{OB}+\mathrm{BV}}{\mathrm{OB}+\mathrm{RB}} \\
& =\frac{\mathrm{BV} \cdot(\mathrm{OB} / \mathrm{BV}+\mathrm{BV} / \mathrm{BV})}{\mathrm{BV} \cdot\left[\mathrm{OB} / \mathrm{BV}+\left(\mathrm{r}_{\mathrm{BV}} \cdot \mathrm{BV} / \mathrm{BV}\right)+\left(\mathrm{r}_{\mathrm{SV}} \cdot \mathrm{SV} / \mathrm{BV}\right)+\mathrm{DOR} / \mathrm{BV}\right]} \\
& =\frac{1+\mathrm{OB} / \mathrm{BV}}{\mathrm{OB} / \mathrm{BV}+\mathrm{r}_{\mathrm{BV}}+\left(\mathrm{r}_{\mathrm{SV}} \cdot \mathrm{SV} / \mathrm{BV}\right)+\mathrm{DOR} / \mathrm{BV}}
\end{aligned}
$$

Vracíme se opět k možnostem regulace peněz v ekonomice centrální bankou. Z rozkladu multiplikátoru je patrné, že vliv lze prosazovat pouze přes sazby povinných minimální rezerv (nezáleží na tom, zda jsou sazby jednotné či nikoli) a popř. také 
úpravou základny těchto rezerv. Pokud by se vztahovaly napřr. pouze na běžné vklady, rozložená podoba by ve jmenovateli neměla sazbu $\mathrm{r}_{\mathrm{SV}}$ ani podíl SV / BV.

Změny sazeb povinných minimálních rezerv mohou mít nepředpokládaný dopad na hodnoty peněžních multiplikátorů. Až na některé minoritní možnosti, jejichž pravděpodobnost je nízká, a proto je necháváme stranou pozornosti, platí, že zvýšení / snížení sazeb vede - s časovým odstupem - ke snížení / zvýšení multiplikátoru. Směr je tedy velmi pravděpodobný, ale co neznáme, je rozsah změny multiplikátoru.

Předpokládejme nyní uvolněnou měnovou politiku, kdy centrální banka sníží sazby povinných minimální rezerv. V prvním kroku se multiplikátor nijak nezmění - rezervy bank zůstanou stejné, pouze se sníží povinné minimální a zvýší dobrovolné rezervy bank. Otázku je, zda takto uvolněné další rezervy banky využijí ke zvýšení nabídky bezhotovostních úvěrů a zda klienti bank na to budou reagovat.

V České republice vzhledem k enormně vysokému podílu dobrovolných rezerv na celkových rezervách bank by taková změna neměla žádný dopad. Obdobné závěry by platily pro opačnou změnu, tj. zvýšení sazeb povinných minimálních rezerv.

Svoji roli mohou mít vzájemné přesuny mezi běžnými a dalšími vklady klientů. Přesun z běžných vkladů do vkladů se splatností do 2 let by sice vedl ke snížení peněžního multiplikátoru měnové agregátu $M 1$, ale nikoli již ke změně multiplikátoru $M 2$, nebot' jeho součástí jsou jak běžné vklady, tak další vklady. Na přesuny mezi vklady navíc centrální banka nemá žádný vliv.

Je proto evidentní, že Česká národní banka má velmi úzký manévrovací prostor pro podporu úvěrové aktivity obchodních bank ve snaze zmírnit deflační tendence a popřr. podpořit ekonomický růst.

Ochota bank poskytovat bezhotovostní úvěry nebankovním subjektům, neboli multiplikace běžných vkladů, je v současnosti spojena především s dostatečně vhodnou poptávkou po úvěrech. Náš bankovní systém jako celek má kromě vysokých dobrovolných rezerv také ,kapitálový polštář“ - kapitálová přiměřenost u kapitálu Tier 1 se pohybuje kolem $17 \%$, tj. více než dvojnásobek požadované výše $(8 \%)$. Možnost snižovat požadavky na kapitálové vybavení bank, která je s ohledem na vývoj regulačních pravidel v Evropě i ve světě čistě hypotetická, by u nás významný efekt neměla. ${ }^{14}$

Vyšší stabilita úvěrového multiplikátoru by dnes, při spíše hypotetické změně procesu měnové politiky České národní banky v podobě cílování inflace, nabízela přechod $\mathrm{k}$ úvěrovému procesu než $\mathrm{k}$ monetaristickému, a to $\mathrm{v}$ modifikované verzi. V základní podobě jde o proces, ve kterém se centrální banka prostřednictvím zvolené krátkodobé úrokové sazby zaměřuje na regulaci vývoje bankovních úvěrů v ekonomice. Modifikace by představovala ovlivňování úvěrů pomocí regulace rezerv bank. ${ }^{15}$

14 Možné změny sazeb povinných minimálních rezerv či základny výpočtu mají nulový dopad na kapitálovou přiměřenost, nebot' povinné minimální i dobrovolné rezervy bank mají nulovou váhu rizikovosti. Naopak, každý poskytnutý bezhotovostní úvěr má kladnou váhu rizikovosti a vždy sníži kapitálovou přiměřenost. Dopady závisejí na různé váze rizikovosti různých druhů úvěrů.

15 V předkrizovém období srov. Brůna (2007). Podrobný popis různých procesů měnové politiky je v Revenda (2011). 
Česká národní banka by tak na první pohled měla mírně lepší možnost odhadovat dopady regulace rezerv bank na vývoj úvěrů v ekonomice, ale vzhledem $\mathrm{k}$ výše uvedeným poznámkám $\mathrm{k}$ nabídce bankovních úvěrů se domníváme, že $\mathrm{k}$ žádným významným protideflačním impulsům by tento způsob nevedl.

Vývoj multiplikátorů je nutné posuzovat komplexněji, nikoli na základě pouhého sledování hodnot. Výrazný pokles multiplikátorů v posledním čtvrtletí roku 2013 by bez toho jednoznačně ukazoval na výrazné snížení ochoty bank poskytovat bezhotovostní úvěry. Připomínáme, že ve skutečnosti byl způsoben dramatickým nárůstem rezerv bank v důsledku snahy České národní banky působit proti deflaci.

\section{Závěr}

Mezi nejvýznamnějšími důsledky poslední finanční krize se objevily neochota obchodních bank i pres růst rezerv poskytovat úvěry do ekonomiky a deflační tlaky. Centrální banky reagovaly kvantitativním uvolňováním, především masivními odkupy dluhových cenných papírů od bank a snižováním vlastních úrokových sazeb. Prakticky stejné projevy je možné sledovat v České republice. Český bankovní systém je však výrazně specifický existencí vysokého podílu dobrovolných rezerv na celkových rezervách bank. Za této situace nemají odkupy cenných papírů větší smysl a ve snižování úrokových sazeb nelze vzhledem k jejich téměř nulovým hodnotám pokračovat.

Především ve snaze zastavit deflační tlaky a vrátit míru inflace k cílované hodnotě $2 \%$ na roční bázi přistoupila Česká národní banka ke třetí, v zásadě poslední možnosti. V listopadu 2013 intervenovala proti koruně s cílem oslabit ji na úroveň 27 korun za euro; použila nesterilizované intervence. To znamená, že bezprostředním efektem, samozřejmě kromě oslabení koruny, byl další enormní nárůst dobrovolných rezerv bank. Nelze očekávat, že dopady na rezervy významně podpoří úvěrovou aktivitu bank, a tím emisi peněz do ekonomiky. Možné zastavení deflačních tlaků tak lze očekávat především přes zvýšení dovozních cen.

Zda bude tento způsob protideflační politiky úspěšný, závisí na více faktorech - kromě již zmíněné úvěrové aktivity bank také na vývoji spotřebitelské poptávky. Výrazně rychlejší růst vkladů domácností ve srovnání s růstem vkladů podniků svědčí o přetrvávající opatrnosti spotřebitelů. Na ní se podílejí především další očekávání deflačního vývoje a nárůst míry zadlužení domácností.

Z pohledu vývoje ve firemním sektoru je varujícím vývoj úvěrů podnikům. Stav úvěrů se v sledovaném období dokonce snížil.

Bezhotovostní peníze jsou do ekonomiky emitovány především bezhotovostními úvěry, které obchodní banky poskytují nebankovním klientům. Každý takový úvěr se souběžně projeví na běžném účtu dlužníka. Vývoj emise lze proto sledovat pomocí multiplikátorů měnových a úvěrových agregátů. Konkrétní závěry je však nutné vždy srovnávat s hlavními př́činami změn multiplikátorů. 


\title{
Literatura
}

BRŮNA, K. 2007. Úrokový transmisní mechanismus a řizení úrokové marže bank v kontextu dezinflační politiky České národní banky. Politická ekonomie. 2007, vol. 55, no. 6, s. 829-851.

GAVIN, W. T.2009. More Money: Understanding Recent Changes in the Monetary Base. Review, Federal Reserve Bank of St. Louis. March/April 2009, vol. 91, no. 2, s. 49-59.

HÜLSMANN, J. G. 2003. Has Fractional-Reserve Banking Really Passed the Market Test? The Independent Review. 2003, vol. 7, no. 3, s. 399-422.

MANDEL, M.; TOMŠíK, V. 2014. Dynamika úvěru v hospodářském cyklu a role makroobezřetnostní politiky. Bankovnictví. 2014, no. 9, speciál I-IV.

MUSÍLEK, P. 2010. Ceny akcií: efektivní nebo behaviorální přístup? Oceňování. 2010, vol. 3, no. 3, s. 50-64.

RASCHE, R. H.; WILLIAMS, M. M. 2007. The Effectiveness of Monetary Policy. Review, Federal Reserve Bank of St. Louis. 2009, vol. 89, no. 5, s. 447-489.

REVENDA, Z. 2013. Centrální bankovnictví. 3. vydání. Management Press : Praha, 2011.

REVENDA, Z. 2013. Peníze a zlato. 2. vydání. Management Press : Praha, 2013.

REVENDA, Z. 2009. Monopoly centrálních bank a emise peněz. Politická ekonomie. 2009, vol. 57, no. 5, s. $579-600$.

\section{CZECH NATIONAL BANK'S INFLUENCE ON THE QUANTITY OF MONEY IN THE ECONOMY}

\begin{abstract}
The latest financial crisis, among other consequences, has led to significant reductions in bank lending. Because cashless bank loans granted to non-bank clients are the dominant way of issue of money into the economy, reducing of them influenced also deflationary pressures. Central banks have tried to respond by expansionary monetary policy in the form of purchases of debt securities from banks and interest rate cuts. However, without any significant effect. Banks did not use a higher quantity of money in the banking system to order to increase granting of loans into the economy. We could observe the similar problems in the Czech Republic. Analysis of data between late 2008 - mid-2014 reliably confirms the weak impact of the Czech National Bank on the development of credit and the quantity of money in the economy. We analyzed data on currency, bank reserves, the monetary base, the monetary aggregates, deposits and loans. Separate analysis concerned the money multipliers and the credit multiplier. The banking system in the Czech Republic is also very specific in the existence of large excess bank reserves. The policy of lowering interest rates by the central bank had not the desired effect, so the only possibility was depreciation of the domestic currency. Another enormous increase in bank reserves as a direct result of unsterilized foreign exchange intervention again did not lead to a significant growth in loans and the quantity of money in the economy. Pressures against deflation can therefore be expected only from the reaction of households and firms to weaker domestic currency.
\end{abstract}

Keywords: capital, central bank, credit, deposit, monetary policy, multiplier, regulation

JEL Classification: E4, E5, G21, G28 